\title{
PENGARUH KOMPETENSI DAN MOTIVASI TERHADAP KINERJA PEGAWAI DI DINAS PEKERJAAN UMUM BINA MARGA PROVINSI SUMATERA SELATAN
}

\author{
Danila \\ Dinas PU Bina Marga Provinsi Sumatera Selatan \\ Email: danila@gmail.com \\ Jefirtson R Riwu Kore \\ Program Magister Universitas Indo Global Mandiri Palembang \\ Email: jefri@uigm.ac.id \\ DOI : 10.35908/jeg.v4i2.754
}

Received: June 11, 2019, Revised: June 20, 2019, Accepted: July 21, 2019

\begin{abstract}
This study discusses competency and motivation for performance in the Public Works Agency of the Highways of South Sumatra Province. The results of this study prove that the dimensions of competence have a significant effect on improving employee performance at the Public Works Agency of the Highways of South Sumatra Province. This can be proven from the results that can be verified between $\mathrm{t}$ count $=3.63$ and $\mathrm{t}$ table $=2.95$. Then the motivation dimension to the performance of employees in the Public Works Agency of Highways of South Sumatra Province does not show more dominant variables on employee performance, this is because the motivation variable has a value of tcount $=2.201<\mathrm{t}$ table $=2.95$.
\end{abstract}

Keywords: Competence, Motivation, Performance, Public Works Agency

\begin{abstract}
ABSTRAK
Penelitian ini membahas tentang pengaruh kompetensi dan motivasi terhadap kinerja pegawai di dinas pekerjaan umum Bina Marga Provinsi Sumatera Selatan. Hasil penelitian ini memperlihatkan bahwa Dimensi kompetensi berpengaruh signifikan terhadap peningkatan kinerja pegawai di Dinas PU Bina Marga Provinsi Sumatera Selatan. Hal ini dapat dibuktikan dari hasil perbandingan antara t hitung = 3.63 dan t tabel $=2.95$. Kemudian dimensi motivasi terhadap kinerja pegawai di Dinas PU Bina Marga Provinsi Sumatera Selatan tidak berpengaruh secara signifikan, terlihat bahwa variabel yang lebih dominan berpengaruh terhadap kinerja pegawai adalah kompetensi, hal ini disebabkan karena variabel motivasi mempunyai nilai thitung $=2.201<\mathrm{t}$ tabel $=2.95$.
\end{abstract}

Kata Kunci : Kompetensi, Motivasi, Kinerja, Dinas Pekerjaan Umum

\section{Pendahuluan}

\subsection{Latar Belakang}

Salah satu tantangan pembangunan adalah melakukan transformasi dan akselerasi pembangunan agar dapat mengatasi masalah yaitu belum terpadu. Salah satunya adalah pengelolahan prasarana dan sarana transportasi. Dalam upaya menjawab tantangan tersebut, pemerintah Provinsi Sumatera Selatan menegaskan bahwa tahapan pembangunan diarahkan untuk mendukung pembangunan menyeluruh di semua bidang, peningkatan daya saing berbasis keunggulan SDM, infrastruktur wilayah, iptek dan suasana wilayah yang kondusif. Salah satu dinas yang menjadi pengelolanya adalah Dinas Pekerjaan Umum. 
Dinas Pekerjaan Umum Provinsi Sumatera Selatan adalah suatu dinas bidang tehnis yang terdiri dari Bidang Pengairan, Bidang Cipta Karya dan Bidang Bina Marga. Bidang Pengairan bergerak dalam pembangunan sumber air bersih, Bidang Cipta Karya bergerak dalam bidang pembangunan dan perumahan, dan Bidang Bina Marga bergerak dalam bidang pembangunan jalan dan jembatan. Tugas pokok, fungsi dan struktur organisasi Dinas Pekerjaan Umum Provinsi Sumatera Selatan diatur berdasarkan Peraturan Daerah Provinsi Sumatera Selatan Nomor 08 Tahun 2008 tentang Organisasi dan Tata Kerja Dinas Provinsi Sumatera Selatan. Berdasarkan Peraturan Daerah tersebut, bahwa Dinas Pekerjaan Umum Provinsi Sumatera Selatan sebagaimana unsur pelaksanaan Pemerintahan Provinsi Sumatera Selatan mempunyai tugas pokok melaksanaan kewenangan desentralisasi dan tugas dekonsentralisasi di bidang Pekerjaan Umum Bina Marga.

Kinerja dipengaruhi oleh berbagai faktor, baik yang berhubungan dengan tenaga kerja itu sendiri maupun faktorfaktor lainnya seperti pendidikan, ketrampilan, disiplin, sikap dan etika kerja, motivasi, gizi dan kesehatan, tingkat penghasilkan, jaminan sosial, lingkungan dan iklim kerja, kesempatan kerja dan kesempatan berprestasi. Guna mencapai kondisi good governance baik di tingkat pusat maupun di daerah dibutuhkan sumber daya manusia yang professional dan bertanggung jawab, sehingga penyelenggaraan pemerintah dan pembangunan dapat accountable, serta bebas korupsi, kolusi dan nepotisme. Berikut kompetensi Pegawai Dinas Pekerjaan Umum Bina Marga Provinsi
Sumatera Selatan dan kinerja keuangan dan anggaran jalan dan jembatan.

Tabel 1.1

\section{Kompetensi Pegawai Dinas PU Bina Marga Provinsi Sumatera Selatan}

\begin{tabular}{|c|c|c|c|c|c|c|}
\hline No & $\begin{array}{c}\text { Tingkat } \\
\text { Pendidikan }\end{array}$ & \multirow{2}{*}{ Jumlah } & \multicolumn{2}{|c|}{ Teknik } & \multicolumn{2}{|c|}{ Non Teknik } \\
\cline { 4 - 7 } & & & Jumlah & \% & Jumlah & \% \\
\hline 1 & Doktor (S3) & 1 & 1 & 100 & - & 0 \\
\hline 2 & Pascasarjana (S2) & 42 & 12 & 30 & 30 & 70 \\
\hline 3 & Sarjana (S1) & 181 & 86 & 47.5 & 95 & 52.5 \\
\hline 4 & Diploma (D4) & 4 & 4 & 100 & - & 0 \\
\hline 5 & Diploma (D3) & 21 & 10 & 48 & 11 & 52 \\
\hline 6 & SLTA Teknik & 145 & 75 & 52 & 70 & 48 \\
\hline 7 & SLTP/SD & 12 & - & 0 & 12 & 100 \\
\hline & $\begin{array}{c}\text { Jumlah } \\
\text { Keseluruhan }\end{array}$ & $\mathbf{4 0 6}$ & $\mathbf{1 8 8}$ & $\mathbf{4 6}$ & $\mathbf{2 1 8}$ & $\mathbf{5 4}$ \\
\hline
\end{tabular}

Sumber : Dinas PU Bina Marga Provinsi

Sumatera Selatan Tahun 2016

Tabel 1.2

Kinerja Keuangan pada Anggaran Jalan dan Jembatan

\begin{tabular}{|c|c|c|c|c|}
\hline No & Tahun & Pagu Anggaran & \multicolumn{2}{|c|}{ Realisasi } \\
\cline { 4 - 5 } & & & Jumlah (Rp) & $\%$ \\
\hline 1 & 2014 & $150.215 .755 .000,00$ & $105.526 .567 .887,50$ & 70.25 \\
\hline 2 & 2015 & $152.352 .438 .900,00$ & $84.638 .255 .931,25$ & 55,55 \\
\hline 3 & 2016 & $160.601 .528 .000,00$ & $112.751 .115 .410,22$ & 70,21 \\
\hline
\end{tabular}

Sumber : Dinas PU Bina Marga Provinsi

Sumatera Selatan Tahun 2016

Dari Tabel di atas, realisasi anggaran selama tiga tahun terakhir masih berkisar 50-70 \%. Motivasi dan kompetensi kerja pegawai dinas yang belum optimal, diduga dapat mempengaruhi kinerja di Dinas PU Bina 
Marga Provinsi Sumatera Selatan. Dengan motivasi kerja yang menyenangkan, seseorang akan mendapatkan suatu ketenangan dalam bekerja sehingga secara langsung maupun tidak langsung akan mempengaruhi kinerjanya. Sumber daya manusia pada dinas dan etos kerja pegawai menjadi salah satu pengukur yang ada dalam penilaian. Kenyataan menunjukkan bahwa sumber daya manusia sebagai salah satu sumber daya yang masih harus ditingkatkan, sehingga mampu mengantisipasi segala tantangan dan kendala dalam persaingan, dengan upaya peningkatan dan pengembangan kemampuan sumber daya manusia tersebut dapat dilakukan melalui pembinaan, pengarahan dan pelatihan yang dilakukan secara berkesinambungan. Kedua hal ini akan lebih dapat dikelola dengan adanya peningkatan kompetensi pegawai dan lebih tingginya motivasi yang diberikan kepada pegawai. Dari latar belakang ini peneliti mengambil judul "Pengaruh Kompetensi dan Motivasi terhadap Kinerja Pegawai di Dinas Pekerjaan Umum Bina Marga Provinsi Sumatera Selatan“.

\subsection{Rumusan masalah}

Berdasarkan identifikasi masalah yang dikemukakan, peneliti merumuskan masalah sebagai berikut :

1. Apakah ada pengaruh kompetensi terhadap kinerja pegawai di Dinas Pekerjaan Umum Bina Marga Provinsi Sumatera Selatan?

2. Apakah ada pengaruh motivasi terhadap kinerja pegawai di Dinas Pekerjaan Umum Bina Marga Provinsi Sumatera Selatan?

3. Apakah ada pengaruh kompetensi dan motivasi terhadap kinerja pegawai di
Dinas Pekerjaan Umum Bina Marga

Provinsi Sumatera Selatan?

\subsection{Tujuan}

Penelitian ini mempunyai tujuan untuk mengetahui pengaruh kompetensi dan motivasi terhadap kinerja pegawai di Dinas Pekerjaan Umum Bina Marga Provinsi Sumatera Selatan.

\section{Metode Penelitian}

\subsection{Metodologi Penelitian}

Metode yang digunakan dalam penelitian ini adalah metode penelitian deskriptif kuantitatif. Menurut Sugiyono, "Penelitian kuantitatif dapat diartikan sebagai metode penelitian yang berlandaskan pada filsafat positivisme, digunakan untuk meneliti pada populasi atau sampel tertentu, pengumpulan data menggunakan instrument penelitian, analisis data bersifat kuantitatif/statistik dengan tujuan untuk menguji hipotesis yang telah ditetapkan.

\subsubsection{Teknik Analisis data}

Adapun teknik analisis data yang digunakan dalam penelitian ini adalah sebagai berikut :

\section{Analisis Regresi Linier berganda}

Analisis regresi linier berganda adalah suatu alat analisis peramalan nilai pengaruh dua variabel bebas atau lebih terhadap variabel terikat untuk membuktikan ada atau tidaknya hubungan fungsi atau hubungan kausal antara dua variabel bebas atau lebih dengan satu variabel terikat.

\section{Analisis Korelasi}


Suatu alat untuk menjelaskan besar kecilnya hubungan antara beberapa variabel independen dan dependen.

\section{Koefisien Korelasi}

Suatu alat untuk menjelaskan besar kecilnya hubungan antara beberapa variabel independen dan dependen.

\subsubsection{Pengujian Hipotesis}

\section{Uji F (Simultan)}

Uji F digunakan untuk menguji pengaruh secara bersama-sama dari variabel kompetensi (X1) dan motivasi (X2) terhadap kinerja pegawai.

\section{Uji t (Parsial)}

Uji t digunakan untuk menguji pengaruh secara individual dari variabel kompetensi (X1) dan motivasi (X2) terhadap kinerja pegawai. Dengan demikian penelitian ini bertujuan mencari dan menyusun secara spesifik, jelas, dan rinci data yang diperoleh dari survei, penyebaran kuesioner atau angket, observasi wawancara dan dokumentasi dari informasi-informasi mengenai pengaruh Motivasi terhadap kinerja pegawai di Dinas Pekerjaan Umum Bina Marga Provinsi Sumatera Selatan.

\section{Pembahasan}

\subsection{Tinjauan Literatur}

\subsubsection{Kinerja}

Sedarmayanti (2007) menyatakan bahwa kinerja merupakan sistem yang digunakan untuk menilai dan mengetahui apakah seorang pegawai telah melaksanakan pekerjaannya secara keseluruhan, atau merupakan perpaduan dari hasil kerja (apa yang harus dicapai seseorang) dan kompetensi (bagaimana seseorang mencapainya). Kinerja meliputi beberapa aspek yaitu; 1) Kualitas Kerja, 2) Ketepatan Waktu, 3) Inisiatif, 4) Kemampuan. Faktor motivasi juga mempengaruhi kinerja.

\subsubsection{Motivasi}

Motivasi merupakan kondisi yang menggerakkan diri pegawai yang terarah untuk mencapai tujuan organisasi (tujuan kerja). Motivasi terbentuk dari sikap seorang karyawan harus siap secara mental, maupun secara fisik dalam memahami tujuan utama dan target kerja yang akan dicapai.

\subsubsection{Kompetensi}

Menurut Robbin, kompetensi adalah suatu kapasitas individu untuk mengerjakan berbagai tugas dalam suatu pekerjaan. Selain itu disebutkan pula bahwa seluruh kemampuan seorang individu pada hakekatnya tersusun dari dua perangkat faktor yaitu kemampuan intelektual dan kemampuan fisik. Definisi tersebut diulang oleh Spencer dan Spencer (1993:9) dalam usaha untuk menjelaskan modal kinerja yang superior berbasis kompetensi. Spencer dan Spencer mengutip demikian: "A competency is an underlying characteristic of an individual that is casually related to criterion-refernced effective and/or superior performance in a job situation." (Spencer \& Spencer, 1993:9). Memperjelas makna definisi tersebut, Spencer dan Spencer menguraikannya kata demi kata. Pertama, underlying characteristic bermakna kompetensi adalah sesuatu yang berada di dalam (fairly deep) dan merupakan bagian yang paling lama bertahan di dalam kepribadian seseorang dan dapat memprediksi perilaku dalam berbagai macam situasi dan berbagai tugas. Kedua, causality related bermakna bahwa 
kompetensi memprediksi perilaku dan kinerja. Terakhir, criterion-referrenced bermakna bahwa kompetensi sebetulnya memprediksi siapa mengerjakan dengan baik atau dengan sangat buruk yang diukur dengan kriteria-kriteria khusus atau standar tertentu.

\subsection{Kerangka Pemikiran}

Berdasarkan tinjauan teoritis tentang kinerja, kompetensi dan motivasi sebagaimana telah diuraikan di atas, selanjutnya penulis mencoba membuat kerangka pemikiran penelitian. Dengan kerangka penelitian ini, diharapkan dapat memberikan gambaran mengenai keterkaitan variabel-variabel yang diteliti. Kerangka pikir penelitian hubungan kompetensi dan motivasi terhadap kinerja akan terlihat seperti pada gambar 2.1. sebagai berikut:

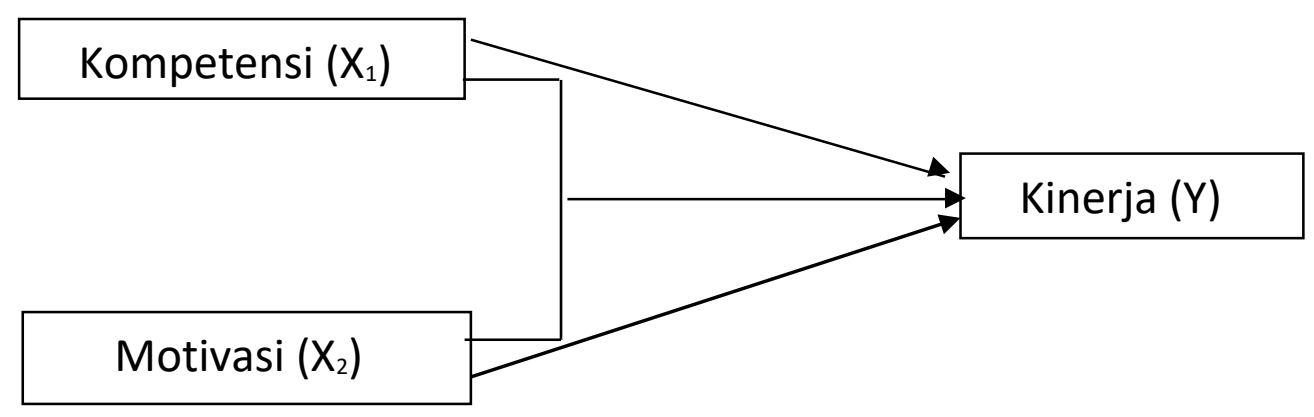

Gambar 2.1 Alur Pikir Penelitian

Dimana :

$$
\begin{array}{ll}
\mathrm{X}_{1} & =\text { Kompetensi } \\
\mathrm{X}_{2} & =\text { Motivasi } \\
\mathrm{Y} & \quad=\text { Kinerja Pegawai }
\end{array}
$$

\subsection{Hipotesis}

Dari model hipotesa yang didasarkan pada model analisa jalur maka dapat disusun hipotes sebagai berikut :

1. Diduga ada pengaruh kompetensi terhadap kinerja pegawai di Dinas Pekerjaan Umum Bina Marga Provinsi Sumatera Selatan

2. Diduga ada pengaruh motivasi terhadap kinerja pegawai di Dinas Pekerjaan Umum Bina Marga Provinsi Sumatera Selatan.
3. Diduga ada pengaruh kompetensi dan motivasi terhadap kinerja pegawai di Dinas Pekerjaan Umum Bina Marga Provinsi Sumatera Selatan

\subsection{Penelitian Terdahulu}

Penelitian ini difokuskan pada variabel kompetensi dan motivasi yang dapat mempengaruhi kinerja pegawai di Dinas Pekerjaan Umum Bina Marga Provinsi Sumatera Selatan. Berikut ini adalah beberapa penelitian terdahulu yang berkaitan dengan penelitian tentang kompetensi, motivasi, dan kinerja. Penelitian sebelumnya yang terkait dengan penelitian ini, adalah:

Anak Agung Ngurah Bagus Dhermawan, Judul penelitian "Pengaruh Motivasi, Lingkungan Kerja, Kompetensi, 
dan Kompensasi terhadap Kepuasan Kerja dan Kinerja Pegawai di Lingkungan Kantor Dinas Pekerjaan Umum Provinsi Bali". Hasil penelitian membuktikan motivasi dan lingkungan kerja berpengaruh tidak signifikan terhadap kepuasan kerja sementara kompetensi dan kompensasi berpengaruh signifikan. Motivasi dan kompetensi berpengaruh tidak signifikan terhadap kinerja pegawai sementara lingkungan kerja, kompensasi dan kepuasan kerja berpengaruh signifikan. Hasil penelitian berimplikasi terhadap motivasi, kondisi lingkungan kerja, kompetensi, dan kompensasi pegawai yang perlu ditingkatkan guna meningkatkan kepuasan kerja dan apabila kepuasan kerja pegawai meningkat maka kinerja pegawai juga akan meningkat.

Anton Moses Junaedy, Judul penelitian "Pengaruh Kompensasi, Kompetensi dan Motivasi terhadap Kepuasan Kerja dan Kinerja Pegawai Unit Penjualan (Sales) UD Sumber Jaya Maha Sakti Motor Purwoharjo Banyuwangi. Hasil penelitian secara parsial kompensasi, kompetensi, dan motivasi berpengaruh positif dan signifikan terhadap kepuasan kerja dan kinerja pegawai. Secara simultan kompensasi, kompetensi, dan motivasi berpengaruh posistif dan signifikan terhadap kinerja pegawai. Sehingga dapat disimpulkan bahwa kompensasi, kompetensi, dan motivasi memiliki pengaruh yang posistif dan signifikan terhadap kepuasan kerja dan kinerja pegawai unit penjualan UD Sumber Jaya Maha Sakti Motor Purwoharjo Banyuwangi.

\section{Hasil Penelitian}

\subsection{Hasil Koesioner Penelitian}

Setiap orang yang bekerja diharapkan mencapai kinerja yang tinggi. Kinerja sebagai hasil dari kegiatan unsurunsur kemampuan yang dapat diukur dan terstandarisasi. Keberhasilan suatu kinerja akan sangat tergantung dan ditentukan oleh beberapa aspek dalam melaksanakan pekerjaan. Agar mencapai kinerja yang optimal hendaknya pengaruh dari faktorfaktor kompetensi diupayakan semaksimal mungkin sesuai dengan area pekerjaan yang dibebankan kepada pegawai. Dengan demikian kompetensi sebagai karakteristik individual diperlukan untuk mencapai kinerja efektif dalam pelaksanaan tugas pekerjaan. Kompetensi dapat dihubungkan dengan kinerja dalam sebuah model alir sebab akibat yang menujukkan bahwa tujuan, perangai, konsep diri, dan kompetensi pengetahuan dibangkitkan oleh suatu keadaan, dapat menimbulkan perilaku-perilaku cakap, yang kemudian mengaktualisasi kinerja.

Tabel 3.1. Deskripsi Responden terhadap Kompetensi Kerja

\begin{tabular}{|c|c|c|c|c|c|c|}
\hline \multirow[b]{2}{*}{ No. } & \multirow[b]{2}{*}{ Pertanyaan } & \multicolumn{5}{|c|}{ Jawaban Responden } \\
\hline & & STS & TS & $\mathrm{N}$ & $\mathrm{S}$ & SS \\
\hline 1. & $\begin{array}{l}\text { Saya menyukai tantangan } \\
\text { yang berhubungan dengan } \\
\text { pekerjaan }\end{array}$ & 1 & 1 & 12 & 25 & 7 \\
\hline 2. & $\begin{array}{l}\text { Saya selalu menetapkan } \\
\text { tujuan yang ingin dicapai } \\
\text { secara realistis }\end{array}$ & 0 & 0 & 10 & 29 & 7 \\
\hline 3. & $\begin{array}{l}\text { Saya selalu ingin menjadi } \\
\text { yang terbaik diantara rekan } \\
\text { kerja yang lain. }\end{array}$ & 0 & 4 & 18 & 18 & 6 \\
\hline 4 & $\begin{array}{l}\text { Saya selalu bersikap } \\
\text { terbuka dengan rekan kerja } \\
\text { yang lain. }\end{array}$ & 0 & 1 & 14 & 21 & 10 \\
\hline 5 & $\begin{array}{l}\text { Saya menikmati persaingan } \\
\text { dengan rekan kerja untuk } \\
\text { mendapatkan jabatan yang } \\
\text { lebih tinggi. }\end{array}$ & 6 & 18 & 15 & 6 & 1 \\
\hline 6 & $\begin{array}{l}\text { Saya tidak merasa } \\
\text { terbebani dengan tanggung }\end{array}$ & 2 & 2 & 10 & 29 & 3 \\
\hline
\end{tabular}




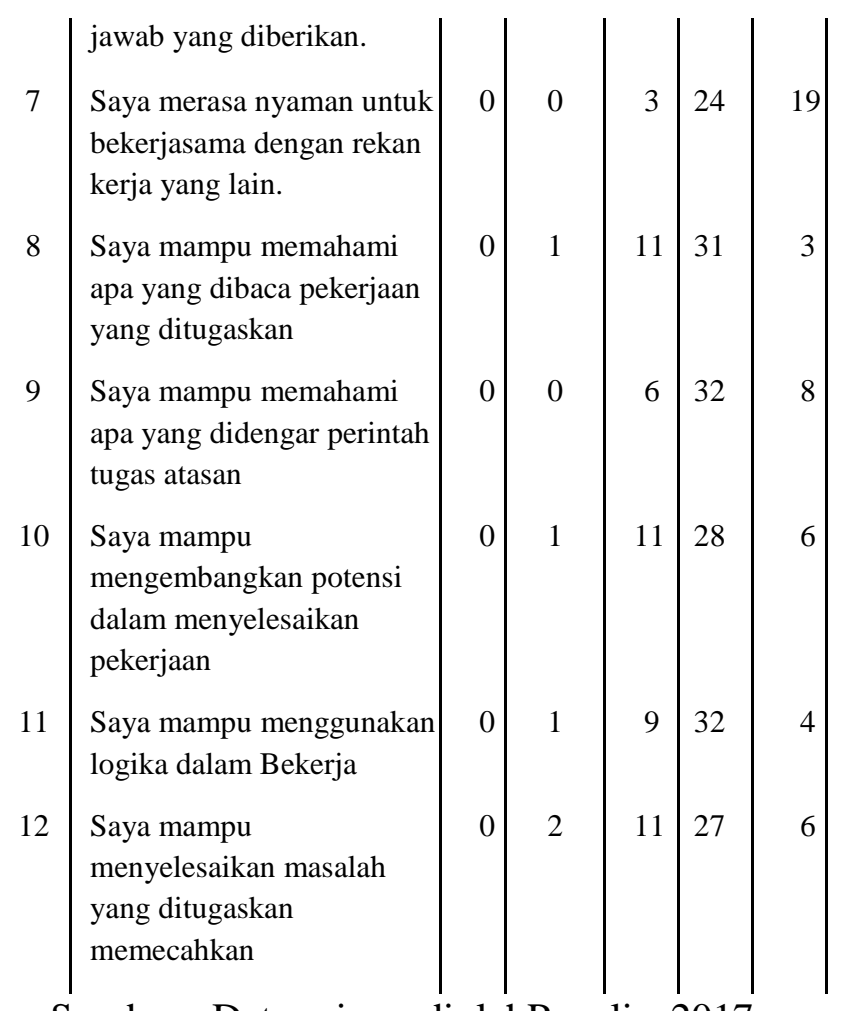

Sumber : Data primer diolahPenulis, 2017

Berdasarkan di atas mengenai deskripsi responden terhadap Kompetensi maka rata-rata responden memberikan jawaban setuju, dapat dilihat dari pernyataan mengenai saya menyukai tantangan yang berhubungan dengan pekerjaan, nampak bahwa sebagian besar responden memberikan jawaban setuju yakni sebesar 25 orang, kemudian pernyataan bahwa saya selalu menetapkan tujuan yang ingin dicapai secara realistis, rata-rata responden memberikan jawaban setuju yakni sebanyak 29 orang, kemudian saya selalu bersikap terbuka dengan rekan kerja yang lain, didominasi jawaban terbanyak responden adalah setuju yakni sebanyak 21 orang, pernyataan bahwa saya tidak merasa terbebani dengan tanggung jawab yang diberikan, maka rata-rata responden memberikan jawaban setuju yakni sebanyak 29 orang, pernyataan saya merasa nyaman untuk bekerja sama dengan rekan kerja yang lain, rata-rata responden memberikan jawaban setuju yakni sebanyak 24 orang, pernyataan saya mampu memahami apa yang dibaca pekerjaan yang ditugaskan, rata-rata responden memberikan jawaban setuju yakni sebanyak 31 orang, pernyataan saya mampu memahami apa yang didengar perintah tugas atasan, rata- rata responden memberikan jawaban setuju yakni sebanyak 32 orang, pernyataan saya mampu mengembangkan potensi dalam menyelesaikan pekerjaan, rata-rata responden memberikan jawaban setuju yakni sebanyak 28 orang, pernyataan saya mampu menggunakan logika dalam bekerja, rata-rata responden memberikan jawaban setuju yakni sebanyak 32 orang, pernyataan saya mampu menyelesaikan memecahkan masalah yang ditugaskan, rata-rata responden memberikan jawaban setuju yakni sebanyak 27 orang.

\subsection{Persepsi Responden mengenai Motivasi Pegawai}

Selain kompetensi maka variabel yang membentuk kinerja adalah motivasi pegawai. Apabila pegawai mempunyai perilaku atau sikap yang mendukung pencapaian tujuan perusahaan, maka secara otomatis segala tugas yang diberikan akan dilaksanakan dengan sebaik-baiknya. Sikap adalah perilaku yang dimiliki oleh masingmasing pegawai dalam menjalankan kegiatan operasionalnya pada dinas. Untuk lebih jelasnya akan disajikan tanggapan responden mengenai perilaku terhadap kinerja pegawai yang dapat dilihat melalui tabel berikut ini :

Tabel 3.2.

Responden Mengenai Motivasi Pegawai Jawaban Responden 


\begin{tabular}{|c|c|c|c|c|c|c|}
\hline No. & Pertanyaan & STS & TS & $\mathbf{N}$ & $\mathbf{S}$ & SS \\
\hline 1. & $\begin{array}{l}\text { Saya selalu mengikuti } \\
\text { pelatihan yang diadakan }\end{array}$ & 0 & 2 & 15 & 22 & 7 \\
\hline 2. & $\begin{array}{l}\text { Tugas yang dibebankan } \\
\text { kepada saya dianggap } \\
\text { sebagai peluang untuk } \\
\text { pengembangan karier. }\end{array}$ & 0 & 1 & 7 & 27 & 11 \\
\hline 3. & $\begin{array}{l}\text { Saya memiliki hubungan } \\
\text { yang erat dengan semua } \\
\text { pegawai }\end{array}$ & 0 & 0 & 10 & 25 & 11 \\
\hline 4. & $\begin{array}{l}\text { Saya lebih suka bekerja } \\
\text { dalam tim untuk } \\
\text { menyelesaikan pekerjaan } \\
\text { yang sulit }\end{array}$ & 0 & 0 & 8 & 23 & 15 \\
\hline 5. & $\begin{array}{l}\text { Saya suka bekerja untuk } \\
\text { mendapatkan lebih banyak } \\
\text { kendali atas peristiwa- } \\
\text { peristiwa di sekitar saya }\end{array}$ & 1 & 6 & 14 & 17 & 8 \\
\hline 6. & $\begin{array}{l}\text { Saya mengetahui segala } \\
\text { kegiatan teknis terkait } \\
\text { dengan lingkup } \\
\text { pekerjaanya. }\end{array}$ & 0 & 3 & 19 & 24 & 13 \\
\hline 7. & $\begin{array}{l}\text { Saya merasakan suatu } \\
\text { kondisi yang aman dalam } \\
\text { bekerja }\end{array}$ & 0 & 0 & 9 & 24 & 13 \\
\hline 8. & \begin{tabular}{|l|} 
Saya merasa nyaman \\
dengan didukung oleh \\
peralatan yang memadai \\
pegawai akan merasa betah \\
dalam bekerja sehari-hari
\end{tabular} & 0 & 0 & 2 & 25 & 19 \\
\hline 9. & $\begin{array}{l}\text { Saya memiliki rasa yang } \\
\text { dapat mendorong kemajuan } \\
\text { akan prestasi kerjanya }\end{array}$ & 0 & 0 & 8 & 31 & 7 \\
\hline 10. & \begin{tabular}{|l} 
Saya dapat melaksanakan \\
pekerjaan yang baik dengan \\
hubungan kerja sesame \\
pegawai dalam bekerja
\end{tabular} & 0 & 0 & 6 & 28 & 12 \\
\hline 11. & $\begin{array}{l}\text { Saya dapat pengakuan dari } \\
\text { rekan kerja terhadap } \\
\text { keberadaan pegawai sebagai } \\
\text { personil yang secara } \\
\text { bersama-sama }\end{array}$ & 1 & 1 & 16 & 24 & 4 \\
\hline 12. & $\begin{array}{l}\text { Organisasi memberikan } \\
\text { penghargaan kepada saya } \\
\text { yang memiliki loyalitas dan } \\
\text { etos }\end{array}$ & 0 & 2 & 12 & 24 & 8 \\
\hline 13. & $\begin{array}{l}\text { Saya merupakan bagian dari } \\
\text { sistem dalam pelaksanaan } \\
\text { peningkatan sumber daya } \\
\text { manusia organisasi }\end{array}$ & 0 & 0 & 11 & 26 & 9 \\
\hline
\end{tabular}

\begin{tabular}{|c|c|c|c|c|c|c|}
\hline 14. & \begin{tabular}{|l} 
Saya suka mempengaruhi \\
orang lain untuk mengikuti \\
cara saya dalam melakukan \\
sesuatu
\end{tabular} & 8 & 14 & 9 & 15 & 0 \\
\hline 15. & $\begin{array}{l}\text { Saya puas dengan } \\
\text { penghasilan yang didapat }\end{array}$ & 0 & 5 & 14 & 24 & 3 \\
\hline 16. & $\begin{array}{l}\text { Saya merupakan bagian dari } \\
\text { sistem dalam pelaksanaan } \\
\text { peningkatan sumber daya } \\
\text { manusia organisasi }\end{array}$ & 0 & 1 & 20 & 21 & 4 \\
\hline 17. & $\begin{array}{l}\text { Saya suka mengerjakan } \\
\text { pekerjaan yang menantang }\end{array}$ & 0 & 3 & 17 & 25 & 1 \\
\hline 18. & $\begin{array}{l}\text { Organisasi memberikan } \\
\text { kenyamanan kerja pada } \\
\text { setiap pegawainya di } \\
\text { lingkungan pekerjaannya }\end{array}$ & 0 & 1 & 13 & 27 & 5 \\
\hline 19 & $\begin{array}{l}\text { Saya dalam melaksanakan } \\
\text { tugasnya dapat } \\
\text { menempatkan diri sebagai } \\
\text { bagian dari system kerja } \\
\text { yang ada }\end{array}$ & 0 & 0 & 9 & 26 & 9 \\
\hline 20. & $\begin{array}{l}\text { Kepercayaan Pemimpin } \\
\text { untuk menentukan } \\
\text { keputusan dalam suatu } \\
\text { pekerjaan membuat saya } \\
\text { bekerja dengan lebih baik } \\
\text { dan tanpa rasa takut }\end{array}$ & 0 & 0 & 4 & 33 & 4 \\
\hline 21. & $\begin{array}{l}\text { Saya memiliki tuntutan } \\
\text { dalam diri pegawai sebagai } \\
\text { yang ditempatkan dalam } \\
\text { unit kerja untuk } \\
\text { melaksanakan pekerjaan } \\
\text { sesuai dengan tugasnya. }\end{array}$ & 0 & 2 & 9 & 26 & 9 \\
\hline 22. & $\begin{array}{l}\text { Saya perlu didukung oleh } \\
\text { suasana yang harmonis } \\
\text { dengan atasan dalam unit } \\
\text { kerja }\end{array}$ & 0 & 0 & 3 & 28 & 15 \\
\hline
\end{tabular}

Berdasarkan tabel di atas mengenai deskripsi responden terhadap motivasi kerja maka rata-rata responden memberikan jawaban setuju, dapat dilihat dari pernyataan mengenai saya selalu mengikuti pelatihan yang diadakan, nampak bahwa sebagian besar responden memberikan jawaban setuju yakni sebesar 22 orang, kemudian pernyataan bahwa tugas yang dibebankan kepada saya dianggap sebagai peluang untuk pengembangan karier, rata-rata responden 
memberikan jawaban setuju yakni sebanyak 27 orang, kemudian saya memiliki hubungan yang erat dengan semua pegawai, didominasi jawaban terbanyak responden adalah setuju yakni sebanyak 25 orang, pernyataan bahwa saya lebih suka bekerja dalam tim untuk menyelesaikan pekerjaan yang sulit, maka rata-rata responden memberikan jawaban setuju yakni sebanyak 23 orang.

\section{Pembahasan}

Peneliti telah melakukan penelitian dengan menggunakan SPSS sebagai alat bantu penelitian. Berikut ini adalah hasil penelitiannya.

\subsection{Analisis Deskriptif}

Adapun hasil analisis deskriptif dapat kita lihat dalam tabel di bawah ini. Adapun hasilnya terlihat dalam penjelasan berikut ini.

1. Jumlah responden yang menjadi sampel 80 orang

2. Rata-rata kinerja pegawai sebesar 65.37 unit dengan standar deviasi sebesar 5.37 unit. Dengan standar deviasi sebesar 5.37 unit, artinya jika dihubungkan dengan rata-rata kinerja pegawai akan berkisar antara $65.37 \pm 5.37$ unit.

3. Kompetensi rata-rata 44.48 dengan standar deviasi sebesar 5.08 dan Motivasi dengan rata-rata 83.42 dengan standar deviasi 7.61. jawaban yang diberikan responden mendekati baik.

Tabel 4.1.

Deskriptif Statistik

\section{Regression}

[Dataseto]

Descriptive Statistics

\begin{tabular}{|l|c|r|r|}
\hline & Mean & Std. Deviation & \multicolumn{1}{|c|}{$N$} \\
\hline Kinerja Pegawai & 65.3750 & 5.37781 & 80 \\
Kompetensi & 44.4875 & 5.08658 & 80 \\
Motivasi & 83.4250 & 7.61872 & 80 \\
\hline
\end{tabular}

Tabel Descriptive Statistic di atas dapat dianalisis :

\begin{tabular}{|ll|r|r|r|}
\hline \multicolumn{2}{|c|}{ Correlations } \\
\hline & $\begin{array}{c}\text { Kineria } \\
\text { Pegawai }\end{array}$ & Kompetensi & Motivasi \\
\hline Pearson Correlation Kinerja Pegawai & 1.000 & .537 & .466 \\
& Kompetensi & .537 & 1.000 & .547 \\
& Motivasi & .466 & .547 & 1.000 \\
\hline Sig. (1-tailed) & Kineria Pegawai & & .000 & .000 \\
& Kompetensi & .000 & & .000 \\
& Motivasi & .000 & .000 & \\
\hline N & Kineria Pegawai & 80 & 80 & 80 \\
& Kompetensi & 80 & 80 & 80 \\
& Motivasi & 80 & 80 & 80 \\
\hline
\end{tabular}

\subsection{Tabel Korelasi}

Korelasi menjelaskan keterkaitan anatar variabel. Adapun tabel korelasi terlihat dari tabel 4.2. di bawah ini

Dari tabel Correlations di atas dapat dianalisis:

1. Hasil perhitungan korelasi antara variabel Kompetensi (X1) dengan Kinerja Pegawai (Y) diperoleh nilai sebesar $r=0.537$. Nilai ini menunjukkan hubungan yang kuat positif. Maksud kuat positif disini adalah terjadi hubungan yang searah antara Kompetensi (X1) dengan Kinerja Pegawai (Y). artinya, bila 
(X1) naik, maka variabel Y akan naik secara signifikan. Kontribusi yang diberikan oleh variabel ini terhadap variabel Y adalah :

$\mathrm{KP}=(\mathrm{r}) 2 \times 100 \%=(0.537) 2 \times 100 \%=28.9 \%$.

2. Hasil korelasi antara variabel Motivasi (X2) dengan Kinerja Pegawai (Y) diperoleh nilai sebesar $r=0.466$. Nilai ini menunjukkan hubungan yang lemah positif. Maksud lemah positif disini adalah terjadi hubungan yang searah antara Motivasi (X2) dengan Kinerja Pegawai (Y). artinya, bila (X2) naik, maka variabel Y tidak naik secara lemah. Kontribusi yang diberikan oleh variabel ini terhadap variabel $\mathrm{Y}$ adalah : $\mathrm{KP}=(\mathrm{r}) 2 \times 100 \%$ $=(0.466) 2 \times 100 \%=21.7 \%$.

\subsection{R Square}

R Square mengukur sebesrapa besar variabel independen dapat menjelaskan variabel dependen. Dimana dependen variabel adalah kinerja dan variabel independen adala motivasi dan kompetensi.

Tabel 4.3.

Tabel R Square

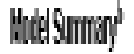

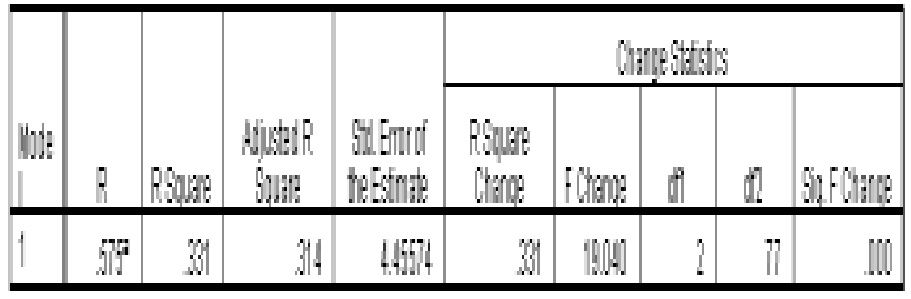

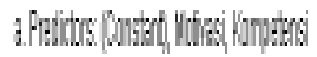

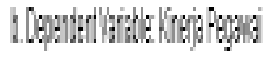

Hasil korelasi (R) yang secara stimulan (bersama-sama) antar variabel Kompetensi (X1) dan Motivasi (X2) terhadap kinerja pegawai (Y) diperoleh nilai sebesar $r=0.575$. Kontribusi yang diberikan oleh kedua variabel ini terhadap variabel Y.

$$
\begin{aligned}
\mathrm{KP} & =(\mathrm{rx} 1, \mathrm{x} 2, \mathrm{Y}) 2 \times 100 \% \\
& =(0.575) 2 \times 100 \%=33.06 \%
\end{aligned}
$$

\subsection{Uji Anova}

Berikut ini merupakan hasil uji Anova dalam penelitian ini. Uji ini dilakukan untuk melihat pengaruh variabel independen dengan variabel dependen.

Tabel 4.4.

\begin{tabular}{|c|c|c|c|c|c|c|}
\hline \multicolumn{7}{|c|}{ AHOYA ${ }^{b}$} \\
\hline Mode. & & $\begin{array}{c}\text { Sum of } \\
\text { Squares }\end{array}$ & df & Mean Square & $F$ & Sig \\
\hline 1 & Regression & 756002 & 2 & 3780011 & 19040 & 000 \\
\hline & Residual & 1528.729 & $\pi$ & 19.854 & & \\
\hline & Total & 22847700 & 79 & & & \\
\hline
\end{tabular}

Uji Anova

a.Predictors: (Constart, Mofrasi, Kompetensi

b. Dependent Variake: Kuneja Pegawai

Kriteria keputusan yang diambil berdasarkan nilai probabilitas

Jika probabilitas (sig) $>\alpha$, maka Ho diterima Jika probabilitas (sig) $<\alpha$, maka Ho ditolak.

-Dari tabel anova nilai probabilitas (sig) $=$ 0.00 dan nilai taraf signifikan $\alpha=0.05$.

-Membandingkan nilai probabilitas (sig) dengan taraf nyata $(\alpha)$ Jika probabilitas $($ sig) $<\alpha$, maka Ho ditolak

Ternyata $0.00<0.05$, maka Ho ditolak

-Keputusannya :

Model regresi linier berganda dapat digunakan untuk memprediksi kinerja pegawai yang dipengaruhi oleh kompetensi dan motivasi pegawai.

\subsection{Uji Koefisien}


Uji ini dilakukan untuk mengetahui pengaruh masing-masing variabel independen terhadap variabel dependen. Dari tabel Coefficients $(\alpha)$ menunjukkan bahwa model persamaan regresi berganda untuk memperkirakan kinerja pegawai yang dipengaruhi oleh kompetensi dan motivasi pegawai adalah :

$\mathrm{Y}=31.972+0.427 \mathrm{X} 1+0.173 \mathrm{X} 2$

$\mathrm{Y}$ adalah kinerja pegawai, $\mathrm{X} 1$ adalah kompetensi dan X2 adalah motivasi. Dari persamaan di atas, dapat dianalisis beberapa hal, antara lain :

1. Kinerja pegawai, jika tanpa adanya kompetensi dan motivasi (X1 dan X2 = $0)$, maka kinerja pegawai hanya 31.972=31 unit. Sedangkan bila masing-masing responden jawabannya bertambah 1 poin untuk jawaban kompetensi dan motivasi (X1=20 dan $\mathrm{X} 2$ = 20), maka diperkirakan kinerja pegawai akan naik menjadi

$$
\begin{aligned}
& Y=31.972+0.427 \mathrm{X} 1+0.173 \mathrm{X} 2 \\
& \mathrm{Y}=31.972+0.427(20)+0.173(20) \\
& Y=44 \text { unit }
\end{aligned}
$$

2. Koefisien regresi berganda sebesar 0.427 dan 0.173 mengindikasikan bahwa besaran penambahan kinerja pegawai setiap pertambahan jawaban responden untuk variabel kompetensi dan motivasi.

3. Persamaan regresi berganda $\mathrm{Y}=31.972$ $+0.427 \mathrm{X} 1+0.173 \mathrm{X} 2$ yang digunakan sebagai dasar untuk memperkirakan kinerja pegawai yang dipengaruhi oleh kompetensi dan motivasi, akan diuji apakah valid untuk digunakan.

Tabel 4.5. Uji Koefisien

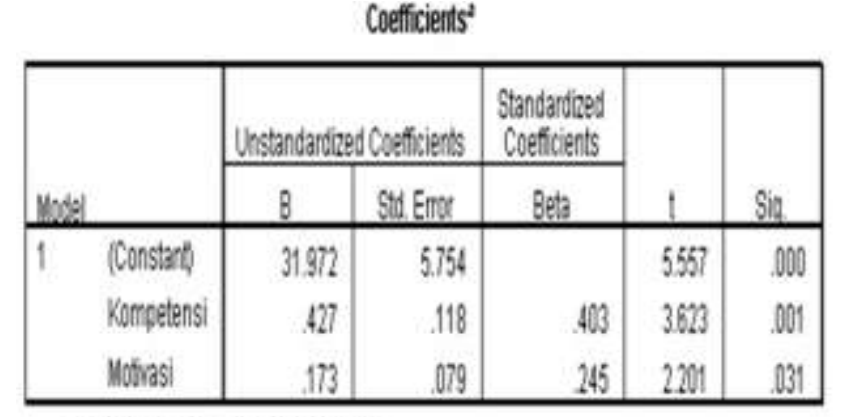

a Dependert Variable: Kneria Pegawa

\section{Penjelasan Uji f dan t}

\section{a.Uji F (simultan)}

Membandingkan antara Fhitung dan Ftabel Tenyata Fhitung $=19.04>$ Ftabel $=12.9$ sehingga Ho ditolak Kesimpulan Uji F

Terdapat pengaruh yang signifikan secara simultan (bersama-sama) antara kompetensi dan motivasi terhadap kinerja pegawai.

\section{b.Uji Parsial}

1. Variabel Kompetensi terhadap Kinerja Pegawai Tenyata thitung $=3.63>$ ttabel $=2.95$, maka Ho ditolak

Kesimpulan variabel kompetensi terhadap kinerja pegawai

Terdapat pengaruh yang signifikan antara kompetensi terhadap kinerja pegawai.

Hipotesis berdasarkan teknik probabilitas, langkah-langkahnya adalah :yaitu sebagai berikut :

Ternyata : Sig $=0.001<0.025$, maka Ho ditolak

Kesimpulan variabel kompetensi terhadap kinerja pegawai

Terdapat pengaruh yang signifikan antara kompetensi terhadap kinerja pegawai.

2. Variabel Motivasi terhadap Kinerja Pegawai 
Tenyata thitung $=2.201<$ ttabel $=2.95$, maka Ho diterima Kesimpulan variabel motivasi terhadap kinerja pegawai adalah :

Tidak terdapat pengaruh yang signifikan antara motivasi terhadap kinerja pegawai.

Hipotesis berdasarkan teknik probabilitas, langkah-langkahnya adalah :yaitu sebagai berikut :

Ternyata : $\mathrm{Sig}=0.031>0.025$, maka Ho diterima

Kesimpulan variabel motivasi terhadap kinerja pegawai adalah :

Tidak terdapat pengaruh yang signifikan antara motivasi terhadap kinerja pegawai.

\section{Pembahasan Hasil Regresi}

Pembahasan ini diarahkan untuk menganalisis pengaruh kompetensi dan motivasi terhadap kinerja pegawai di Dinas PU Bina Marga Provinsi Sumatera Selatan, selain itu untuk mengetahui variabel manakah yang lebih dominan yang mempengaruhi peningkatan kinerja pegawai di Dinas PU Bina Marga Provinsi Sumatera Selatan yang dapat diuraikan sebagai berikut :

1) Pengaruh kompetensi terhadap kinerja pegawai

Hasil analisis regresi antara kompetensi dengan kinerja pegawai, menunjukkan bahwa peningkatan tanggapan mengenai kompetensi dapat diikuti oleh adanya peningkatan kinerja pegawai. Oleh karena nilai value yang lebih kecil dari 0,05 maka dapat dikatakan bahwa kompetensi berpengaruh terhadap peningkatan kinerja pegawai. Hal ini disebabkan karena pengetahuan merupakan modal dasar untuk dapat memberikan kontribusi yang baik pada dinas, mampu meningkatkan efektivitas kerja, mampu membantu pegawai dalam mencapai tujuan dinasserta dengan adanya kompetensi yang semakin tinggi maka semakin tinggi pula kinerja pegawai dalam dinas.

Dari hasil penelitian terdahulu sebagaimana yang dilakukan oleh Rosman Effendi (2009) yang meneliti mengenai pengaruh kompetensi terhadap kinerja pegawai pada Kantor Pelayanan Pajak Metro, dimana ditemukan bahwa kompetensi berpengaruh terhadap kinerja pegawai pada Kantor Pelayanan Pajak Metro. Begitu pula dengan penelitian yang dilakukan oleh Dewinanti (2008) yang meneliti mengenai pengaruh kompetensi sumber daya manusia terhadap kinerja pegawai pada PT. Nusantara III Deli Serdang-2 Sel Karang Galang. Hasil penelitian menemukan bahwa kompetensi berpengaruh secara simultan terhadap kinerja pegawai.

Kemudian jika dikaitkan dengan penelitian yang peneliti lakukan nampak bahwa kompetensi mempunyai pengaruh yang signifikan terhadap peningkatan kinerja pegawai di Dinas PU Bina Marga Provinsi Sumatera Selatan.

2) Pengaruh motivasi kerja dengan kinerja pegawai

Berdasarkan hasil olahan data regresi, maka diperoleh nilai beta untuk keterampilan kerja sebesar 0.248 serta memiliki nilai pvalue $0.171>0,05$. Berarti dapat dikatakan bahwa motivasi tidak berpengaruh secara signifikan dengan kinerja pegawai sebesar 0,248\%. Kemudian dalam pembuktian uji signifikan maka diperoleh nilai thitung sebesar0.248 dan pvalue $=0,171>0,05$, sehingga dapat dikatakan bahwa motivasi kerjatidak berpengaruh secara signifikan terhadap 
peningkatan kinerja pegawai di Dinas PU Bina Marga Provinsi Sumatera Selatan sehingga dalam meningkatkan pegawai.

Hasil penelitian yang dilakukan oleh penulis, terlihat bahwa motivasi tidak berpengaruh secara signifikan terhadap kinerja pegawai. Sehingga dapat ditarik kesimpulan bahwa variabel yang lebih dekat mempengaruhi kinerja pegawai adalah kompetensi, alasannya karena memiliki nilai thitung $=3.63>$ ttabel $=$ 2.95. nilai thitung lebih besar dibandingkan nilai ttabel maka Ho ditolak. Terdapat pengaruh yang signifikan antara kompetensi terhadap kinerja pegawai.

\section{Kesimpulan dan Saran}

\subsection{Kesimpulan}

Adapun kesimpulan yang dapat diberikan sehubungan dengan hasil penelitian dan pembahasan ini dapat diuraikan sebagai berikut :

\section{Dimensi Dimensi kompetensi berpengaruh signifikan terhadap peningkatan kinerja pegawai di Dinas PU} Bina Marga Provinsi Sumatera Selatan. Hal ini dapat dibuktikan dari hasil perbandingan antara thitung $=3.63$ dan ttabel $=2.95$, yang menghasilkan $\mathrm{Ho}$ ditolak sehingga Kesimpulan variabel kompetensi terhadap kinerja pegawai adalah terdapat pengaruh yang signifikan antara kompetensi terhadap kinerja pegawai. Dapat dikatakan bahwa kompetensi mempunyai pengaruh yang signifikan terhadap peningkatan kinerja pegawai, dengan demikian maka hipotesis pertama yang diajukan terbukti kebenarannya.

2. Dimensi motivasi terhadap kinerja pegawai di Dinas PU Bina Marga
Provinsi Sumatera Selatan tidak berpengaruh secara signifikan, terlihat bahwa variabel yang lebih dominan berpengaruh terhadap kinerja pegawai adalah kompetensi, hal ini disebabkan karena variabel motivasi mempunyai nilai thitung $=2.201<$ ttabel $=2.95$, maka Ho diterima sehingga kesimpulannya tidak terdapat pengaruh yang signifikan antara motivasi terhadap kinerja pegawai. Dan dapat dikatakan bahwa kompetensi mempunyai pengaruh yang signifikan terhadap peningkatan kinerja pegawai, dengan demikian maka hipotesis pertama yang diajukan terbukti kebenarannya. Dengan demikian hipotesis kedua yang telah diajukan tidak terbukti kebenarannya.

\subsection{Saran}

Dari hasil analisis dan pembahasan serta kesimpulan yang telah dikemukakan, maka saran-saran yang dapat diberikan dari hasil penelitian ini yaitu sebagai berikut :

1. Disarankan kepada Kepala Dinas PU Bina Marga Provinsi Sumatera Selatan agar dalam meningkatkan kompetensi pegawai, dengan melakukan diklat guna dapat meningkatkan pengetahuan dan keterampilan kepada pegawai di masa yang akan datang.

2. Disarankan pula agar dalam meningkatkan kinerja pegawai maka perlunya memperhatikan masalah kompetensi pegawai, khususnya yang berkaitan dengan keterampilan kerja pegawai dalam menangani setiap pekerjaan yang diberikan.

3. Mengingat bahwa variabel yang paling dominan berpengaruh adalah kompetensi maka disarankan agar dinas dalam memberikan insentif maka 
perlunya memperhatikan mengenai masa kerja atau senioritas

\section{Daftar Pustaka}

Allan, Thoma. 1997. Motivasi dan Produktifitas Kerja. Jakarta: BPK Gunung Mulia

Dinas Pekerjaan Umum (DPU), 2015, Rencana dan Strategi Dinas Pekerjaan Umum, Palembang, Dinas Pekerjaan Umum Sumatera Selatan.

Firdaus, Zamzam Fakhry, 2018 Aplikasi Metodologi, Yogyakarta, Penerbit Deepublish

Hadari Nawawi. (2005). Manajemen Sumber Daya Manusia. Yogyakarta: Gadjah Mada University Press.

Hasibuan, Malayu. 2012. Manajemen Sumber Daya Manusia. Bumi Aksara : Jakarta

Hartono. (2004). Statistik Untuk Penelitian. Yogyakarta: Lembaga Studi Filsafat, Kemasyarakatan, Kependidikan dan Perempuan $\left(\mathrm{LSFK}_{2} \mathrm{P}\right)$

Kadarisman. (2012). Manajemen Pengembangan Sumber Daya Manusia. Jakarta: Raja Grafindo Persada.

Listio, Ronald. 2010. Pengaruh Kompetensi dan Motivasi Kerja Terhadap Kinerja Karyawan PT.Allianz Life Indonesia Wilayah Jawa Barat. Tesis. Program Pasca Sarjana Universitas Komputer Indonesia. Bandung
Malayu S.P. Hasibuan. (2006). Manajemen Sumber Daya Manusia. Jakarta: Bumi Aksara

Maslow, Abraham. 1994. Motivasi dan Kepribadian. Jakarta : Pustaka Banawan

Nazir, Moh. 1983. Metode Penelitian. Ghalia Indonesia : Jakarta

Robert L. Mathis, John H. Jackson. (2001). Manajemen Sumber Daya Manusia. Jakarta: Salemba Empat.

Robbins, S.P. 2001. Perilaku Organisasi. Jakarta: PT. Indeks Kelompok Gramedia.

Sedarmayanti. 2001. Sumber Daya Manusia dan Produktivitas Kerja.Bandung: Mandar Maju

Zamzam, Fakhry, Havis Aravik, 2016. Manajemen SDM Berbasis Syariah, Bogor: CV. RWTC Success

Zamzam, Fakhry, 2015, Teknik Dasar Penulisan Proposal Tesis, Palembang, Penerbit Noerfikri

\section{Jurnal Ilmiah}

Agung Ngurah Bagus Dhermawan, Anak. 2012. Pengaruh Motivasi, Lingkungan Kerja, Kompetensi, dan Kompensasi terhadap Kepuasan Kerja dan Kinerja Pegawai di Lingkungan Kantor Dinas Pekerjaan Umum Provinsi Bali

Anton Moses Junaedy, Dewi Prihatini, Markus Apriono. 2014. Pengaruh Kompensasi, Kompetensi dan Motivasi terhadap Kepuasan Kerja dan Kinerja Karyawan Unit 
Penjualan (Sales) UD Sumber Jaya Maha Sakti Motor Purwoharjo Banyuwangi. Jurnal Ilmiah Mahasiswa.

Ataunur, ilman. 2015. Pengaruh Kompetensi dan Pelatihan terhadap Kinerja Karyawan PT Adaro Energy Tbk.

Nur Fu'ad, Eko. 2016. Pengaruh Kompetensi dan Motivasi Kerja terhadap Kinerja Manajer Koperasi di Kabupaten Jepara.

Safwan, Nadirsyah, dan Syukriy Abdullah. 2014. Pengaruh kompetensi dan motivasi terhadap kinerja pengelolaan keuangan daerah Kabupaten Pidie Jaya. Jurnal Akuntansi

Srie Wijaya Kesuma Dewi. 2015. Telaah Hubungan Kompetensi, Motivasi dan Kinerja Karyawan.

Sriwidodo, Untung. Pengaruh Kompetensi, Motivasi, Komunikasi dan Kesejahteraan terhadap Kinerja Pegawai Dinas Pendidikan.

Suprapto.2009. Pengaruh Kompetensi dan Motivasi Kerja terhadap Kinerja Pegawai dengan Kepuasan sebagai Moderating Variabel.

Syah, Muhibbin. 1995. Kepimpinan dan Motivasi (Teori Herzberg). Jakarta:Rieneka Cipta

Wahyu Nur Rohmah. (2013). Pengaruh Motivasi Kerja dan Pelatihan Kerja Terhadap Kinerja Karyawan Pada Kantor Pelayanan Pajak Pratama Bantul : FE UNY. 